Bangladesh J. Bot. 47(4): 921-926, 2018 (December)

\title{
PRODUCTIVITY AND WATER USE EFFICIENCY OF BREAD WHEAT (TRITICUM AESTIVUM L.) AS INFLUENCED BY IRRIGATION SCHEDULE, MULCHING AND HYDROGEL IN EASTERN INDO-GANGETIC PLAINS OF INDIA
}

\author{
SP Singh, RK Singh, SK Prasad and Neelam Bisen* \\ Department of Agronomy, Institute of Agricultural Sciences, \\ Banaras Hindu University, Varanasi-221005, India
}

Keywords: Productivity, Water use efficiency, Irrigation scheduling, Straw mulch, Hydrogel

\begin{abstract}
A field experiment was conducted to evaluate the influence of limited and adequate irrigation and moisture conservation practices (rice straw mulch and hydrogel) on yield and water use efficiency in wheat. Though, maximum wheat yield (3.92 t/ha) and water use efficiency $(15.72 \mathrm{~kg} / \mathrm{ha} / \mathrm{mm})$ was recorded with four irrigations at crown root initiation stage, tillering, late jointing, and milk stage, two irrigations applied at tillering and flowering and soil mix drilling of $7.5 \mathrm{~kg} /$ ha hydrogel (a synthetic polymer) at sowing produced comparable yield (3.34 t/ha) with less water use, enhancing the water use efficiency $(15.45 \mathrm{~kg} / \mathrm{ha}-\mathrm{mm})$. The higher net return and B : C ratio were found in the treatment $2.5 \mathrm{~kg} /$ ha hydrogel. Thus, from present study it may be concluded that under limited irrigation conditions, water conservation practices like soil mix drilling of hydrogel and rice-straw mulching are beneficial for maintaining optimum moisture in soil to enhance wheat yield and water use efficiency.
\end{abstract}

\section{Introduction}

Wheat (Triticum aestivum L.) is widely grown crop of the world and satiates the food security and wide adaptability in different agro-climatic conditions. The issue of water management has assumed paramount importance and occupied the centre stage of politico-economic debates in the world. India has already entered the shadow of the zone of physical and economic water scarcity. Scheduling of irrigation based on phenological stages (crown root, tillering, booting, anthesis, soft dough and hard dough stage) in wheat has been practical approach to the farmers in different wheat growing zones in India. Wheat response to water stress from stem elongation to booting, followed by anthesis and grain-filling stages (Zhang et al.1999). Application of limited irrigation gets maximum yield and saves water compared to more irrigation schedules on wheat (Khokhar et al. 2010).

Effect of mulching in conserving moisture and increasing productivity of wheat has been reported (Sarwar et al. 2013). Combination of irrigation with mulch is advocated to improve water uptake and to reduce number of irrigation in the spring wheat (Li et al. 2004). Hydrogel a semisynthetic super absorbent polymer has shown the potential to realize more yield per drop of water (Jalilian and Mohsennia 2013) and reduces the leaching of herbicides, fertilizer and irrigation requirement of crops (Mehr and Kourosh 2008). Research is limited on combined effect of mulch, hydrogel and irrigation scheduling in wheat under semi-arid environment of Eastern IndoGangetic Plains of India. In the present study attempts were made to evaluate the effect of adequate and limited irrigation scheduled at critical stages with moisture conservation practices viz., mulching and hydrogel on yield and consumptive use of water and WUE in wheat.

*Author for correspondence: <neelam.bisen25@gmail.com>. 


\section{Materials and Methods}

An experiment was conducted for 2 years in a sandy loam soil at Banaras Hindu University Varanasi, $\left(25^{\circ} .18^{\prime} \mathrm{N}\right.$ latitude, $83^{\circ} .03^{\prime} \mathrm{E}$ longitude and 75.5 meteraltitude), Uttar Pradesh, India, during 2012 - 2014. The area is under subtropical semi-arid climate with moisture deficit index of -20 to $-40 \%$ and experiences hot and dry summer (April-June), hot-humid monsoon period (July - September) and mild to cold winter (October - February). The rainfall pattern varied to a great extent during two years of study as shown in Table 1. In 2012 - 2013 the Pan-evaporation during December, January, February, March, April and May were 33.4, 44.9, 56.9, 128.3 and $128.3 \mathrm{~mm}$, respectively. In 2013 - 2014 the PET during December, January, February, March, April and May were $34.7,37.1,53.7,116.3$ and $129.9 \mathrm{~mm}$, respectively. The experimental soil was sandy clay loam in texture with a $\mathrm{pH}$ of 7.2. It was moderately fertile being low in mean organic carbon $0.35 \%$ and available $\mathrm{N} 206.60 \mathrm{~kg} / \mathrm{ha}$, phosphorous $17.67 \mathrm{~kg} / \mathrm{ha}$, potash $238.0 \mathrm{~kg} / \mathrm{ha}$. Factorial experiment was laid out in a randomized complete block design and replicated thrice. Eighteen treatments combinations comprised of three irrigation schedules viz., no irrigation, one irrigation at crown root initiation and two irrigation at tillering and flowering and six moisture conservation treatments viz. without mulch and hydrogel, 4 t/ha mulch, 6 t/ha mulch, $2.5 \mathrm{~kg}$ hydrogel $/ \mathrm{ha}, 5.0 \mathrm{~kg}$ hydrogel/ha and $7.5 \mathrm{~kg}$ hydrogel/ha were compared with recommended irrigation schedule based on phonological stages (crown root initiation, tillering, late jointing and milk stage) of wheat. Quantity of irrigation water was measured with parshall flume to a depth of $5 \pm 2 \mathrm{~cm}$ and applied as per irrigation schedule. Wheat variety HD 2733 was line sown at a row spacing of $22.5 \mathrm{~cm}$. using $125 \mathrm{~kg}$ seeds $/ \mathrm{ha}$. A uniform basal rate of $60 \mathrm{~kg} \mathrm{~N} / \mathrm{ha}, 60 \mathrm{~kg} \mathrm{P} / \mathrm{ha}$ and $40 \mathrm{~kg} \mathrm{~K} / \mathrm{ha}$ was applied in all the treatments combinations, except un irrigated crop which received $120 \mathrm{~kg} \mathrm{~N} / \mathrm{ha}$ as basal with $\mathrm{P}$ and $\mathrm{K}$. Remaining half nitrogen was applied at 30 days after sowing in rest of the treatments. Hydrogel was mixed with soil and applied in the band of seed line at the time of sowing. Rice straw mulch was spread in inter-rows 3 days after sowing. Soil moisture determination was done using gravimetric method. Soil samples were drawn with the help of screw auger from $0-15,15-30,30-60$ and $90 \mathrm{~cm}$ soil depth before sowing and before and after of each irrigation. The moisture percentage from different soil depths was used to calculate consumptive use of water and soil moisture extraction pattern of the crop for irrigation treatments. Soil moisture depletion pattern from different layers were measured at $0-15,15-30$ and $30-60$ $\mathrm{cm}$ and $90 \mathrm{~cm}$ depths by sunflower plant indicator method (Dastane 1972).

Table 1. Rainfall pattern according to irrigation schedules in both years.

\begin{tabular}{lcc}
\hline Rainfall (mm) & $2012-13$ & $2013-14$ \\
\hline Before CRI (1 - 21 days) & 0 & 0 \\
CRI to T (22 - 42 days) & 0 & 63.4 \\
T to LJ (43 - 63 days) & 0 & 24.4 \\
LJ to milking (64 - 85 days) & 66.8 & 50 \\
Milking to harvesting (86 - 120 days) & 9.6 & 0 \\
Total & $76.4 \mathrm{~mm}$ & $137.8 \mathrm{~mm}$ \\
\hline
\end{tabular}

$\mathrm{CRI}=$ Crown root initiation, $\mathrm{T}=$ Tillering, $\mathrm{LJ}=$ Late jointing.

Consumptive use of water $(\mathrm{cm})=\sum_{\mathrm{i}=1}^{\mathrm{n}}$ Total moisture depleted + soil moisture contribution $+\mathrm{ER}$ Water use efficiency $(\mathrm{kg} / \mathrm{ha} / \mathrm{mm})=\frac{\text { Grain yield }(\mathrm{kg} / \mathrm{ha})}{\text { Total consumptive use of water }(\mathrm{mm})}$ 
The statistical analysis of variance was done by using the Fischer's method as described by Gomez and Gomez (1984). The level of significance used in ' $F$ ' and ' $t$ ' test was $p=0.05$ and LSD values were calculated wherever the 'F' test was significant. Since, the trends in treatment effects on parameters studied were non-significant between years the data were pooled for presentation.

\section{Results and Discussion}

The maximum growth parameters were recorded in recommended four irrigations scheduled at CRI, tillering, late jointing, and milk stage which was significantly higher than one irrigation schedule at CRI and no irrigation, but comparable to two irrigations at tillering and flowering (Table 2).

Table 2. Irrigation scheduling and moisture conservation practices on growth parameters at harvest of wheat (mean of 2012-13 and 2013-14).

\begin{tabular}{|c|c|c|c|c|c|}
\hline \multirow[t]{2}{*}{ Treatments } & \multicolumn{4}{|c|}{ Growth parameters } & \multirow{2}{*}{$\begin{array}{c}\text { Physiological } \\
\text { characteristics }\end{array}$} \\
\hline & $\begin{array}{l}\text { Plant height } \\
\text { (cm) }\end{array}$ & $\begin{array}{l}\text { LAI at } 90 \\
\text { DAS }\end{array}$ & $\begin{array}{c}\text { No. of } \\
\text { tillers } / \mathrm{m}^{-2}\end{array}$ & $\begin{array}{l}\text { Dry matter } / \mathrm{m} \\
(\mathrm{g})\end{array}$ & \\
\hline \multicolumn{6}{|l|}{ Irrigation schedules } \\
\hline $\mathrm{I}_{0}$ (No irrigation) & 94.44 & 2.26 & 267.50 & 194.97 & 1.19 \\
\hline $\mathrm{I}_{1}$ (One irrigation) & 104.47 & 2.88 & 291.46 & 215.78 & 1.42 \\
\hline $\mathrm{I}_{2}$ (Two irrigations) & 113.21 & 2.95 & 315.24 & 235.04 & 1.59 \\
\hline $\mathrm{SEm} \pm$ & 0.63 & 0.01 & 0.86 & 0.38 & 0.02 \\
\hline $\mathrm{CD}(\mathrm{p}=0.05)$ & 1.28 & 0.02 & 1.73 & 0.76 & 0.03 \\
\hline \multicolumn{6}{|c|}{ Moisture conservation practices } \\
\hline $\mathrm{M}_{1}$ (Nothing used) & 98.57 & 2.54 & 279.74 & 205.48 & 1.36 \\
\hline $\mathrm{M}_{2}(4 \mathrm{t} \mathrm{mulch} / \mathrm{ha})$ & 102.10 & 2.66 & 291.03 & 216.02 & 1.39 \\
\hline $\mathrm{M}_{3}(6 \mathrm{t} \mathrm{mulch} / \mathrm{ha})$ & 106.08 & 2.73 & 296.76 & 216.77 & 1.41 \\
\hline $\mathrm{M}_{4}(2.5 \mathrm{~kg}$ hydrogel $/ \mathrm{ha})$ & 103.60 & 2.74 & 287.07 & 215.29 & 1.38 \\
\hline $\mathrm{M}_{5}(5 \mathrm{~kg}$ hydrogel $/ \mathrm{ha})$ & 106.04 & 2.75 & 293.75 & 217.72 & 1.42 \\
\hline $\mathrm{M}_{6}(7.5 \mathrm{~kg}$ hydrogel $/ \mathrm{ha})$ & 107.86 & 2.76 & 300.06 & 220.31 & 1.44 \\
\hline $\mathrm{SEm} \pm$ & 1.26 & 0.02 & 1.71 & 0.75 & 0.03 \\
\hline$C D(p=0.05)$ & 2.55 & 0.05 & 3.47 & 1.52 & 0.07 \\
\hline $\mathrm{I} \times \mathrm{M}$ & NS & NS & NS & NS & NS \\
\hline C (Four irrigations) & 108.92 & 3.02 & 310.00 & 226.59 & 1.39 \\
\hline $\operatorname{SEm} \pm$ & 4.75 & 0.08 & 6.46 & 2.83 & 0.12 \\
\hline $\mathrm{CD}(\mathrm{p}=0.05)$ & 9.63 & 0.17 & 13.09 & 5.74 & 0.25 \\
\hline
\end{tabular}

Increase in growth parameters at higher moisture regime might be due to maintenance of adequate and continuous moisture to plant which maintained good establishment of roots and various metabolic processes. Moisture conservation produced significant variation in plant height, LAI, number of tillers/m, dry matter accumulation and crop growth rate at harvest stage during both years. These findings are in accordance with the findings of Ahmad (2002). Among moisture conservation treatments, hydrogel at $7.5 \mathrm{~kg} / \mathrm{ha}$ was significantly superior to the rest of treatments, except mulching at $6 \mathrm{t} / \mathrm{ha}$, in plant height, number of tillers $/ \mathrm{m}$, and dry matter accumulation by crop (Table 2). Mulching is known to increase moisture storage in soil which increases absorption and utilization of nutrients from soil, thus increasing the size of source and increase the activity of 
cell division,cell expansion and cell elongation, ultimately leading to an increased growth parameters (Al-Harbi et al.1996).

The maximum grain yield was recorded with two irrigation schedules at tillering and flowering and was significantly superior to irrigation applied only at CRI $\left(\mathrm{I}_{1}\right)$ and no irrigation $\left(\mathrm{I}_{0}\right)$, but on par to four irrigations. Similarly, $I_{1}$ was significantly superior over $I_{0}$ (Table 3). Yield is the function of vegetative development; it might be due to maintained adequate available soil moisture (ASM) in the root zone throughout the crop growth period. The present findings are similar with the findings of Mubeen et al. (2012).

Table 3. Effect of irrigation scheduling and moisture conservation practices on yield attributes, total consumptive use, and WUE at harvest and economics of wheat (mean of 2012-13 and 2013-14).

\begin{tabular}{|c|c|c|c|c|c|c|c|}
\hline Treatments & $\begin{array}{l}\text { Grain } \\
\text { yield } \\
(\mathrm{t} / \mathrm{ha})\end{array}$ & $\begin{array}{l}\text { Straw } \\
\text { yield } \\
(\mathrm{t} / \mathrm{ha})\end{array}$ & $\begin{array}{l}\text { Biological } \\
\text { yield (t/ha) }\end{array}$ & $\begin{array}{c}\text { Total } \\
\text { consumptive } \\
\text { use }(\mathrm{mm})\end{array}$ & $\begin{array}{l}\text { Water use } \\
\text { efficiency } \\
(\mathrm{kg} / \mathrm{ha}-\mathrm{mm})\end{array}$ & $\begin{array}{c}\text { Net } \\
\text { returns } \\
\text { (Rs./ha) }\end{array}$ & $\begin{array}{l}\mathrm{B}: \mathrm{C} \\
\text { ratio }\end{array}$ \\
\hline \multicolumn{8}{|c|}{ Irrigation schedules } \\
\hline $\begin{array}{l}\mathrm{I}_{0} \text { (No } \\
\text { irrigation) }\end{array}$ & 2.51 & 2.88 & 5.39 & 206.08 & 12.36 & 17438 & 0.6 \\
\hline $\begin{array}{l}\mathrm{I}_{1} \text { (One } \\
\text { irrigation) }\end{array}$ & 3.27 & 3.74 & 7.05 & 212.89 & 15.51 & 30663 & 1.1 \\
\hline $\begin{array}{l}\mathrm{I}_{2} \text { (Two } \\
\text { irrigations) }\end{array}$ & 3.92 & 4.49 & 8.42 & 227.14 & 17.31 & 42063 & 1.4 \\
\hline $\mathrm{SEm} \pm$ & 0.17 & 0.18 & 0.35 & 0.09 & 0.09 & 287.08 & 0.0099 \\
\hline $\mathrm{CD}(\mathrm{p}=0.05)$ & 0.35 & 0.36 & 0.70 & 0.19 & 0.17 & 823.38 & 0.029 \\
\hline \multicolumn{8}{|c|}{ Moisture conservation practices } \\
\hline $\begin{array}{l}\mathrm{M}_{1} \text { (Nothing } \\
\text { used) }\end{array}$ & 2.88 & 3.34 & 6.25 & 214.21 & 13.44 & 28838 & 1.2 \\
\hline $\begin{array}{l}\mathrm{M}_{2}(4 \mathrm{t} \\
\text { mulch/ha) }\end{array}$ & 3.23 & 3.71 & 6.94 & 214.91 & 15.09 & 29933 & 1.0 \\
\hline $\begin{array}{l}\mathrm{M}_{3}(6 \mathrm{t} \\
\mathrm{mulch} / \mathrm{ha})\end{array}$ & 3.33 & 3.79 & 7.12 & 215.20 & 15.51 & 29627 & 0.9 \\
\hline $\begin{array}{l}\mathrm{M}_{4}(2.5 \mathrm{~kg} \\
\text { hydrogel } / \mathrm{ha})\end{array}$ & 3.31 & 3.77 & 7.17 & 215.92 & 15.38 & 33367 & 1.2 \\
\hline $\begin{array}{l}\mathrm{M}_{5}(5 \mathrm{~kg} \\
\text { hydrogel/ha })\end{array}$ & 3.32 & 3.79 & 7.13 & 215.95 & 15.49 & 30813 & 1.0 \\
\hline $\begin{array}{l}\mathrm{M}_{6}(7.5 \mathrm{~kg} \\
\text { hydrogel/ha })\end{array}$ & 3.34 & 3.82 & 7.14 & 216.03 & 15.45 & 27750 & 0.8 \\
\hline $\mathrm{SEm} \pm$ & 0.35 & 0.36 & 0.69 & -- & -- & 574.15 & 0.0198 \\
\hline$C D(p=0.05)$ & 0.71 & 0.73 & 1.41 & 0.37 & 0.35 & 1646.76 & 0.057 \\
\hline $\mathrm{I} \times \mathrm{M}$ & NS & NS & NS & -- & NS & & \\
\hline $\begin{array}{l}\mathrm{C} \text { (Four } \\
\text { irrigations) }\end{array}$ & 3.92 & 4.54 & 8.47 & 249.37 & 15.72 & 45996.92 & 1.7 \\
\hline $\mathrm{SEm} \pm$ & 1.32 & 1.36 & 2.62 & 0.69 & 0.64 & 1722.46 & 0.0594 \\
\hline $\mathrm{CD}(\mathrm{p}=0.05)$ & 2.67 & 2.75 & 5.32 & 1.40 & 1.31 & 4940.28 & 0.196 \\
\hline
\end{tabular}

Amongst moisture conservation practices, maximum grain, straw and biological yield were recorded with $\mathrm{M}_{6}(7.5 \mathrm{~kg}$ hydrogel $/ \mathrm{ha})$ which was at par with $\mathrm{M}_{3}(6 \mathrm{t} \mathrm{mulch} / \mathrm{ha})$ and $\mathrm{M}_{5}(5 \mathrm{~kg}$ hydrogel/ha). These treatments were significantly superior to $\mathrm{M}_{1}$ (no moisture conservation practice) and $\mathrm{M}_{2}(4 \mathrm{t}$ mulch/ha). Hydrogel hade been reported to increase the growth attributes that 
lead to increased yield attributes and crop yield (Sendur et al. 2001). Mulch being a barrier to evaporation loss, maintained more moisture in the soil which supported more number of ear heads and enabled them to bear more grains and finally crop yields (Huang et al. 2005).

Application of mulch and hydrogel affected net return and benefit cost ratio B : C ratio markedly. The net return and benefit cost ratio were numerically higher in treatment four irrigation (45997 Rs./ha and 1.7) and followed by two irrigation (42063 Rs./ha and 1.4 ) and $2.5 \mathrm{~kg}$ hydrogel/ha (33367Rs./ha and 1.2). This might be due to the increase in grain yield with frequent irrigations applied in this treatment.

Table 4. Interaction effect of irrigation scheduling and moisture conservation practices on grain yield of wheat.

\begin{tabular}{lccccccc}
\hline Treatments & \multicolumn{9}{c}{ Grain yield } & Mean \\
\cline { 2 - 7 } & $\mathrm{M}_{1}$ & $\mathrm{M}_{2}$ & $\mathrm{M}_{3}$ & $\mathrm{M}_{4}$ & $\mathrm{M}_{5}$ & $\mathrm{M}_{6}$ & \\
\hline $\mathrm{I}_{0}$ (No irrigation) & 2.19 & 2.51 & 2.61 & 2.58 & 2.55 & 2.57 & 2.50 \\
$\mathrm{I}_{1}$ (One irrigation) & 2.88 & 3.29 & 3.33 & 3.33 & 3.36 & 3.38 & 3.26 \\
$\mathrm{I}_{2}$ (Two irrigation) & 3.56 & 3.89 & 4.02 & 4.02 & 4.04 & 4.03 & 3.93 \\
Mean & 2.88 & 3.23 & 3.32 & 3.31 & 3.32 & 3.32 & \\
$\mathrm{CD}(\mathrm{p}=0.05)$ & \multicolumn{7}{c}{$\mathrm{NS}$} \\
\hline
\end{tabular}

Table 5. Interaction effect of irrigation scheduling and moisture conservation practices on total consumptive use of water on wheat.

\begin{tabular}{|c|c|c|c|c|c|c|c|}
\hline \multirow{2}{*}{$\begin{array}{l}\text { Treatments } \\
2012-13\end{array}$} & \multicolumn{6}{|c|}{ Total consumptive use (mm) } & \multirow[t]{2}{*}{ Mean } \\
\hline & $\mathrm{M}_{1}$ & $\mathrm{M}_{2}$ & $\mathrm{M}_{3}$ & $\mathrm{M}_{4}$ & $\mathrm{M}_{5}$ & $\mathrm{M}_{6}$ & \\
\hline $\mathrm{I}_{0}$ (No irrigation) & 173.83 & 178.45 & 178.80 & 180.12 & 179.14 & 180.02 & 178.39 \\
\hline $\mathrm{I}_{1}$ (One irrigation) & 184.05 & 184.18 & 186.70 & 187.52 & 187.86 & 188.68 & 186.50 \\
\hline $\mathrm{I}_{2}$ (Two irrigation) & 210.35 & 210.50 & 211.10 & 210.33 & 211.16 & 211.17 & 210.77 \\
\hline Mean & 189.46 & 190.99 & 192.20 & 192.66 & 192.72 & 193.29 & \\
\hline
\end{tabular}

The total consumptive water use was maximum in control, but WUE was maximum with two irrigation schedules at tillering and flowering (Table 5). This might be due to sufficient and continued supply of water for high evapo-transpiration from vegetation (Tadayon et al. 2012). Amongst moisture conservation practices, total consumptive use and water use efficiency were higher in $\mathrm{M}_{6}\left(7.5 \mathrm{~kg}\right.$ hydrogel $/ \mathrm{ha}$ ) followed by $\mathrm{M}_{5}(5 \mathrm{~kg}$ hydrogel $/ \mathrm{ha})$ and $\mathrm{M}_{3}(6 \mathrm{t} \mathrm{mulch} / \mathrm{ha})$ for water use efficiency. Minimum total consumptive use and WUE in $\mathrm{M}_{1}$ (no moisture conservation practice). WUE increased due to mulching because evapo-transpiration becomes less in inter rows. Whereas, application of hydrogel to the soil helped in retaining more moisture in the soil, increased water holding capacity of soil and decreased infiltration rate of soil (Vizaylaxmi et al. 2012). Consequently, better crop growth and yield were obtained under hydrogel at higher rates than lower rate and also the alone application of mulch. The treatment combinations of $\mathrm{I}_{2} \mathrm{M}_{6}$ (two irrigations with $7.5 \mathrm{~kg}$ hydrogel $/ \mathrm{ha}$ ) recorded maximum consumptive use of water than all other combinations of irrigation schedules and moisture conservation treatments. However, $I_{2}$ in combination with all the moisture conservation practices recorded higher consumptive use than other combination of irrigation and moisture conservation practices. Hydrogel improved water holding capacity and nutrient supplying capacity because it retains larger amount of water and 
increased the size 500 - 1000 times. Thus, it reduces the losses and provide water slowly to plant. Similar finding was also observed by Rostampour (2013).

From the present study, it may be inferred that under limited water availability two irrigations at CRI and flowering stages of wheat and $7.5 \mathrm{~kg}$ hydrogel $/ \mathrm{ha}$ be applied for higher growth yield and water use efficiency of wheat.

\section{References}

Ahmad A 2002. Effect of irrigation scheduling on the performance of wheat genotypes invertisols, M.Sc. (Agri.) Thesis, University of Agricultural Sciences, Dharwad.

Al-Harbi AR, Al Omran AM, Choudhary MI, Wahdan H and Mursi M 1996. Influence of soil conditioner on seed germination and growth of cucumber. Arab Gulf. Journal of Scientific Research 14(1): 129-142.

Dastane NG 1972. A Practical Manual for Water Use Research in agriculture. Navabharat Prakashan Publications, Poona (India), pp. 5-6.

Gomez KA and Gomez AA 1984. Statistical Procedures for Agricultural Research, $2^{\text {nd }}$ edition, a Wiley-Inter Science Publication, New York (USA), pp. 196-211.

Khokhar B, Hussain I and Khokhar Z 2010. Effect of different irrigation frequencies on growth and yield of different wheat genotypes in Sindh. Pakistan J. Agr. Res. 23: 108-113.

Huang YL, Chen LD, Fu BJ, Huang Z and J 2005. The wheat yields and water-use efficiency in the Loess Plateau: straw mulch and irrigation effects, Agricultural Water Management 72(3): 209-222

Jalilian, $\mathrm{J}$ and Mohsennia $\mathrm{O}$ 2013. Effects of superabsorbent and irrigation regime on seedling growth characteristics of barley (Hordeum vulgare L.). Cercetari Agronomice in Moldova 46(155): 11-19.

Li YF, Li XZ, Zhou LC, Zhu XX and Li BN 2004. Study on the synthesis and application of salt resisting polymer hydrogel. Polymers for Advanced. Technology 15: 34-38.

Mehr MJZ and Kourosh K 2008. Superabsorbent Polymer Materials: A Review. Iranian Polymer Journal 17(6): 451-477.

Mubeen M, Ahmad A, Wajid A, Khaliq T, Sultana RS, Hussain S, Ali A, Ali H and Nasim W 2013. Effect of growth stage-based irrigation schedules on biomass accumulation and resource use efficiency of wheat cultivars. American Journal of Plant Sciences 4: 1435-1442.

Rostampour MF 2013. The effect of irrigation regimes and polymer on several physiological traits of forage sorghum. Asian Journal of Agriculture and Food Science 1(5): 274-281.

Sarwar MA, Akbar N, Muhammad H, Javeed R, Shehzad MA, Mehmood A and Abbas HT. 2013. Response of Zero Tilled Wheat Crop to Different Mulching Techniques in a Semiarid Environment. International J. Advanced Res. 1(9): 768-776.

Sendur Kumaran S, Natrajan S, Muthve I and Sathiayamurthy VA 2001. Efficacy of graded doses of polymers on processing quality of tomato cv. CO 3. Journal of Madras Agriculture 88(4-6): 298-299.

Tadayon RM, Ebrahimi R and Tadayyon A 2012. Increased water productivity of wheat under supplemental irrigation and nitrogen application in a semi-arid region. Journal of Agriculture Science Technology 14: 995-1003.

Vijayalakshmi, Nemichandrappa M, Reddy KS and Ayyanagowdar MS 2012. Effect of polymers on moisture retention and soil water holding capacity. Karnataka Journal of Agriculture Sciences 25(4): 469-471.

Zhang $\mathrm{H}$ and Oweis $\mathrm{T}$ 1999. Water-yield relation and optimal irrigation scheduling of wheat in the Mediterranean region. Agricultural. Water Management 38: 195-211.

(Manuscript received on 8 February, 2018 revised on 9 June, 2018) 